\title{
Perspective
}

PERSPECTIVE Actualité en histoire de l'art

$1 \mid 2015$

Varia

\section{Conceptions and reworkings of baroque and neobaroque in recent years}

conceptions et déterminations récentes du baroque et du néobaroque

Claire Farago, Helen Hills, Monika Kaup, Gabriela Siracusano, Jens Baumgarten and Stefano Jacoviello

Translator. Susan Wise

1 Journals

Electronic version

URL: http://journals.openedition.org/perspective/5792

DOI: 10.4000/perspective.5792

ISSN: 2269-7721

Publisher

Institut national d'histoire de l'art

Printed version

Date of publication: 31 July 2015

Number of pages: 43-62

ISBN: 978-2-917902-26-4

ISSN: $1777-7852$

Electronic reference

Claire Farago, Helen Hills, Monika Kaup, Gabriela Siracusano, Jens Baumgarten and Stefano Jacoviello, "Conceptions and reworkings of baroque and neobaroque in recent years ", Perspective [Online], 1 | 2015, Online since 31 January 2017, connection on 07 July 2020. URL : http://

journals.openedition.org/perspective/5792 ; DOI : https://doi.org/10.4000/perspective.5792 


\title{
Conceptions and reworkings of baroque and neobaroque in recent years
}

\author{
A discussion moderated by Helen Hills with Jens Baumgarten, Claire \\ Farago, Stefano Jacoviello, Monika Kaup, and Gabriela Siracusano
}

Baroque needs to be thought across chronological and geographical divides to connect architecture and dance, painting and natural science, philosophy, sculpture and music (and not in the sense of representations of music) and, above all, in relation to encounters with difference - heavenly, earthly, social, political, religious, geographical. What possibilities in baroque are open now in relation to present dilemmas in art history and world events?

Baroque enables - arguably, it demands - a radical rethinking of historical time - and a rethinking of familiar history. It permits a liberation from periodization and linear time, as well as from historicism. While the scholars below acknowledge that baroque is often equated with style or historical period, it is most productively thought beyond them. Mieke Bal has argued that baroque epistemology permits an "hallucinatory quality" of relation between past and present that also allows a release from a supposed academic objectivity, while insisting that the engagement with the past should remain discomfiting and profoundly disturbing. ${ }^{1}$ Instead of repressing the past and time, creative retrospection allows its implications to emerge. In its materiality and bodiliness, baroque undermines resolution, gropes towards fragmentation, overgrows, and exceeds. Baroque architecture may be seen as overflowing, an excess of ornamental exteriority and evasive proliferation. This brings to the fore the question of surface. Andrew Benjamin's approach to surface as neither merely structural nor merely decoration in architecture is important here. Baroque time and form impinge on each other - that is, not simply the time that it takes to process point of view into form, but of form into point of view. ${ }^{2}$ Thus the pursuit is for a baroque vision of vision, a baroque audition of hearing, and a multitemporality. The question of materiality (not mere matter, materials, or technique) must also come into play.

While Heinrich Wölfflin insists on a chronological periodization for baroque (broadly, the sixteenth century), even as he identifies formal characteristics that may exceed that periodization, Walter Benjamin and Gilles Deleuze in particular permit baroque to free itself from such an anchor. ${ }^{3}$

Irlemar Chiampi writes: "The Baroque, with its historical and geographical, not to mention aesthetic, eccentricity, confronts the historicist canon (the new 'classicism') constructed in the hegemonic centers of the Western world, thereby functioning to redefine the terms according to which Latin America enters into the orbit of Euro-American modernity. The Baroque, crossroads of signs and temporalities, aesthetic logic of mourning and melancholy, luxuriousnesss and pleasure, erotic convulsion and allegorical pathos, reappears to bear witness to the crisis or end of modernity and to the very condition of a continent that could not be assimilated by the project of the Enlightenment."
Claire Farago is Professor of

Renaissance art, theory, and criticism at the University of Colorado-Boulder. Her publications include Art Is Not What You Think It Is (2012).

Helen Hills is Professor of Art History at the University of York. She has published extensively on baroque art and architecture and is completing a monograph on miracles and baroque materiality.

Monika Kaup is Professor in English and adjunct Professor in Comparative Literature at the University of Washington. Her projects include Neobaroque in the Americas (2012).

Gabriela Siracusano is a researcher for the CONICET, professor of art history, and director of the Centro de Investigación en Arte, Materia y Cultura (Universidad Nacional de Tres de Febrero).

Jens Baumgarten is Professor of Art History at the Universidade Federal de São Paulo and a researcher at the Conselho Nacional de Desenvolvimento Científico e Tecnológico (CNPq).

Stefano Jacoviello teaches Semiotics of Culture and History of Music at the University of Siena. He is involved as scientific coordinator in several international research projects on performing heritage. 


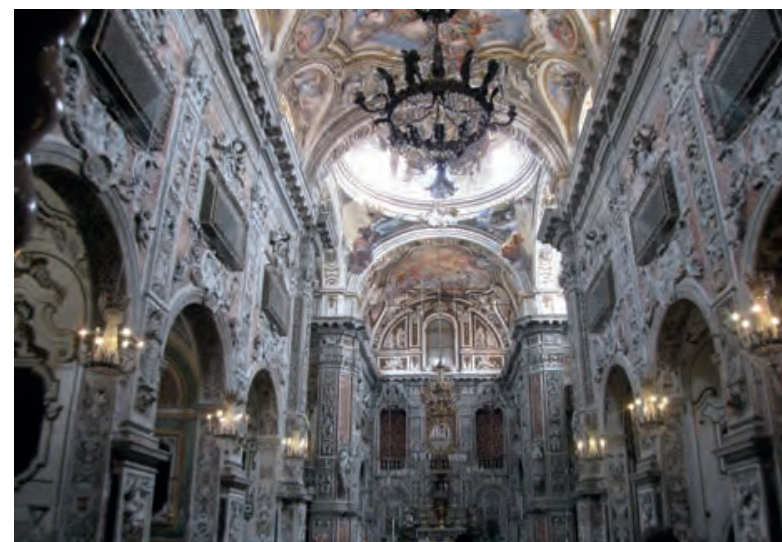

Yet "baroque as Counter-Reformation" already too hastily elides baroque and Counter-Reformation. Certainly, this has been the dominant model within European scholarship on European baroque. But it is a perennial cliché, endlessly reiterated but rarely critically examined. In the great churches of Pallavicino in Bologna the cry of the Counter-Reformation resounds. But this is far from the situation in Naples or Sicily where the greatest adventures of the baroque take place (figs. 1-2). Baroque is far more than a first response to the spiritual crisis of the Reformation. Hostilities to Muslims, Moriscos and Jews arguably have as much purchase as anti-Protestantism.

Arguably, the deficiencies of "baroque as

1. Church of Santa Caterina, Palermo.
2. Lorenzo Vaccaro (attrib.), St. Mary of Egypt, silver reliquary, Naples, Chapel of the Treasury of San Gennaro.

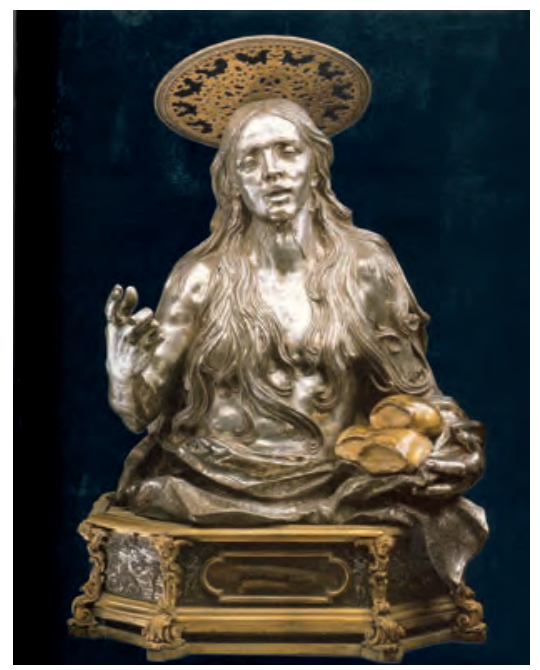
Counter-Reformation" come most sharply to light, less within most studies of the Old World than in relation to their implications in the "New." While the limiting effects outside Old Europe of what is, after all, a representational (and reactionary) mode of conceptualizing baroque within Europe become more readily and horribly apparent outside Europe, this does not mean that this is a problem to be addressed only outside of Europe. Far from it. It is vital to recall that the Spanish monarchy took advantage of baroque for its imperializing projects within Europe, as well as beyond it. Thus while scholarship that looks beyond Europe is urgently required, the Europel non-Europe paradigm is unhelpful in thinking about baroque's effects and impulses. A rethinking of the paradigms of baroque and of the so-called "Counter-Reformation" within Europe is thus urgently required. Indeed, arguably, it is precisely here that new paradigms are most urgently needed. This should send us back to "Old Europe" as much as to Latin America - with a desire to re-examine, this time far more critically, precisely those most familiar and outworn Old European paradigms.

Might scholarship of baroque in Latin America usefully be redeployed in relation to European baroque? "Why is Latin America the chosen territory of the baroque?" asks Alejo Carpentier, "Because all symbiosis, all mestizaje, engenders the baroque." ${ }^{5}$ How might baroque Europe be thought in terms of mestizaje? Does baroque exhalt in the ineradicable character of antagonism? If New World baroque emerges as more than a faithful imitation of the colonial model, more than simply a "top down" imposition by colonialists, but something new, original, a rebellious affirmation of a nascent mestizo American culture, generated through the minoritization of a colonial model at the hands of the subjected users who were forced to inhabit it, then what are the implications of this for Spanish colonized Flanders or Italy?

How might the potential that baroque offers in relation to history - including history of art, music, literature - and conceptions of the past be best seized? In what ways might baroque decenter familiar narratives of the "long seventeenth century"? Part of baroque's greatest potential is in terms of historical time. History is too readily mobilized for political ends. Resisting periodization assists in thwarting simple historicism. Instead of subjecting time to chronology, Walter Benjamin's allegorical way of seeing grasps the constellation which one era has formed with an earlier one, opening a possibility of resistance to the catastrophe of modernity. Deleuze's theory of the baroque fold, in contrast, investigates the baroque as a creative 
principle. ${ }^{6}$ Together they demonstrate baroque's rich potential. Baroque as a nonobjectivist mode might explore slippages between appearance and truth, deception and insight. On the other hand, it might reiterate these tropes precisely as a means to halt a rethinking of history and thus also of an opening of a different future. One needs only to consider the usefulness of baroque to the absolutists. It is, rather, the untapped possibilities within baroque that can now be engaged. But must baroque inevitably be seen in relation to "modernity"? There is a risk here of seeing the past only in relation to a certain conception of the present's concern with the present, not as an opening afforded within that present, but as simply leading in a more teleological sense to its own conventional representation of itself to itself. To think "across" chronologies already depends on some recognition of them; thus the issue of temporality and of a history that is not historicist emerges as central. Baroque brings discrepancy and rupture, not simply harmony: the shattering of what was taken for granted. This is not a question of linear time: baroque is always already contemporary. Fold and scale are already at play and one is enfolded in what one studies: point of view involves selfreflection, a self-awareness and self-consciousness. A serious engagement with history as a problem should prevent this from being a simply narcissistic matter. The fold involves the subject within materialist experience, but the matter or materiality extends beyond the subject. [Helen Hills ${ }^{7}$ ]

Helen Hills. How useful is the term "baroque" in your current research? Do you use it? What do you see as its principal opportunities and traps?

Monika Kaup. I am currently exploring new approaches to conceptualizing the baroque and neobaroque as a "networked" aesthetics of complexity. On the one hand, this speaks to the formal characteristics of baroque and neobaroque expression - excess, ornateness, de-centering proliferation (the anti-minimalist principle of "more is more"). But it is also a continuation of my efforts to resolve the impasse of what Walter Moser calls the "conceptual Babel" of the baroque. ${ }^{8}$ My comparative study Neobaroque in the Americas: Alternative Modernities in Literature, Visual Art, and Film focused on finding a way of theorizing the transhistorical and transcultural continuities of the baroque and neobaroque in ways that would neither dismiss the original European baroque nor shortchange the heterogeneity of the "new" baroques that have emerged in its wake. As I argued there, after four centuries of nonlinear development across multiple boundaries among nations, ethnic groups, historical periods, and disciplines, we have to dispense with the notion of one single baroque, the property of segregated social groups and disciplines. A new "image of thought" (Deleuze) has to be found to account for the multiplicity of baroques accumulated by centuries of nonlinear development: the European baroque (a continental formation and the cultural logic of early modern authoritarianism - absolutism and the CounterReformation); the New World baroque (the rebellious, de-colonizing offshoots of the European baroque in Europe's colonies in the Americas), and the neobaroque (the recuperation and revival of the seventeenth-century baroque in twentieth- and twenty-first-century literature, visual art, film, and philosophy). Examples of neobaroque theoretical reconceptualizations of the baroque include: a "timeless," transhistorical style (Eugenio d'Ors); the medium of rebellious anti-colonial Latin American expression (Ángel Guido; Alejo Carpentier; José Lezama Lima); the alternative modernity of the Hispanic world (Irlemar Chiampi and Bolívar Echeverría) - the list goes on. 
3. Cupola, Church of Santa María Tonantzintla (1690-1730), State of Puebla, Mexico.

4a. Jesse Valadez, Gypsy Rose, 1964 Chevrolet Impala; b. Mike Lopez, Twilight Zone, 1962 Chevrolet Impala SS, interior with custom-tailored velour upholstery, swivel chairs, wet bar, and decorative skulls.
In Neobaroque in the Americas, I suggested that - against the grain of familiar scholarly attempts to "own" the baroque (by the Hispanophone world, or by the discipline of art history) - the baroque and neobaroque today must be recognized as an "open system" or hybrid network, a kind of non-totalizable whole: "the baroque refuses to regard culture as a fixed, 'self-contained system,' the property of discrete, segregated social groups. Rather, the baroque is an 'anti-proprietary expression' that brings together seemingly disparate writers and artists; few artistic and representational phenomena are so good at bending so many ways as the baroque." ${ }^{\prime}$ Evidence of this is the existence of neobaroques in Anglo American modernism (T. S. Eliot and Djuna Barnes), largely ignored because of Anglophone culture's ingrained wariness of the baroque. Eliot and Barnes, paralleling the Spanish Generation of '27's recovery of the baroque poet Luis de Góngora, or the Mexican vanguardista Contemporáneos' recuperation of New World baroque writers such as Sor Juana and Bernardo de Balbuena, contributed to the neobaroque revival and rehabilitation of baroque writers and artists by reclaiming the English metaphysical poets (Eliot) and Robert Burton and early modern melancholia (Barnes) respectively. Further afield, the baroque-neobaroque network connects, for example, Góngora with the hip-hop baroque, in works by the contemporary African American artist Kehinde Wiley and Cuban American artist Luis Gispert. And the baroque strategy of rebellious stylization and re-creation of the icons of dominant Western culture links eighteenth-century Mexican folk baroque churches such as the Church of Santa María Tonantzintla (fig. 3) with the rasquache baroque in contemporary Chicano culture, such as Chicano lowrider automobiles (fig. 4). ${ }^{10}$

In short, the transhistorical and transcultural conti-

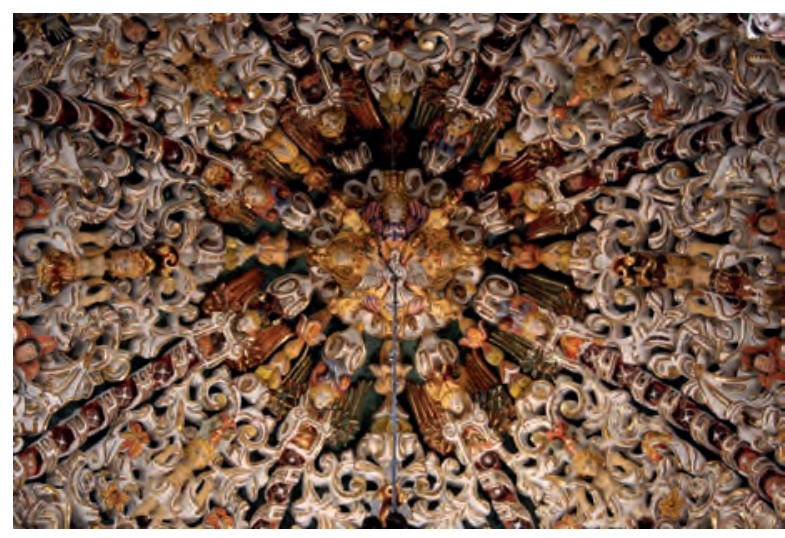

nuities of the baroque and neobaroque pose the problem of theorizing emergence and the phenomenon of re-origination. How do we understand the appearance of "new" baroques, some of which go against the social meanings the baroque had at its origins in Europe? My new project explores links between the baroque and contemporary "holistic" and network theories, such as complexity theory (the theory of dynamic or self-organizing systems), and Bruno Latour's actor-network theory. ${ }^{11}$ These theories offer new ways of conceptualizing the complex historical aggregate of the baroque network. Dynamic systems are those operating far from equilibrium, which have self-
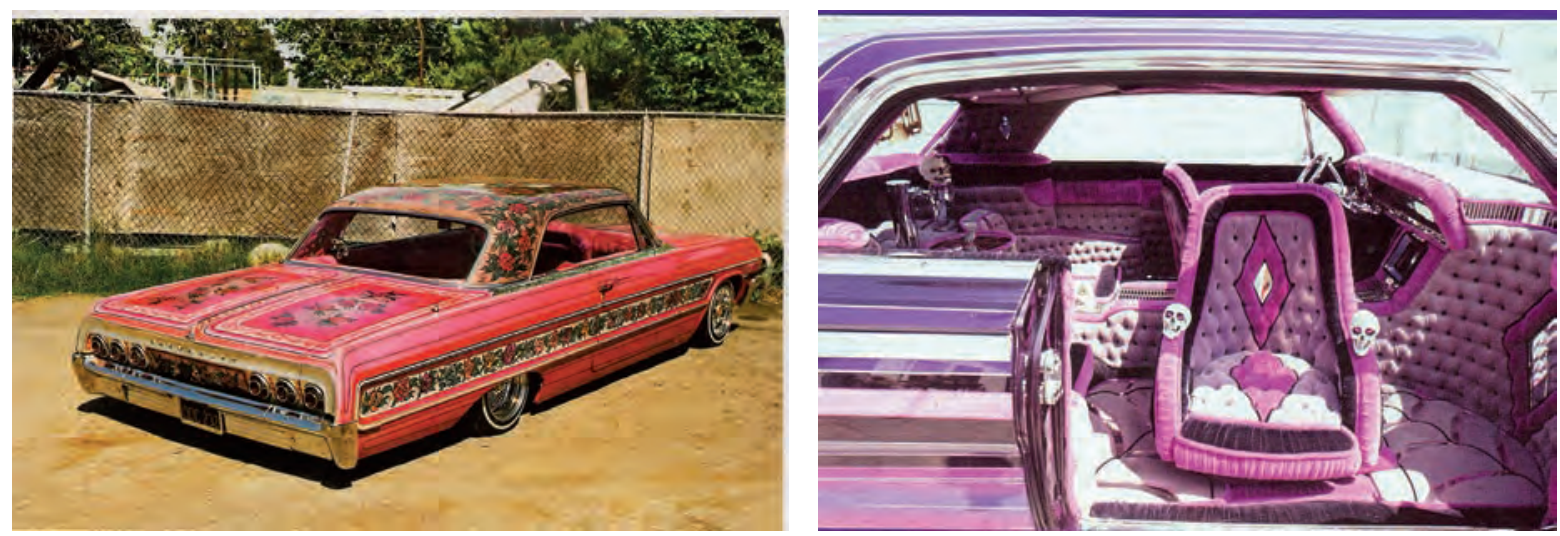
regulating mechanisms, multiple causality, and interactive feedback loops that allow the system to maintain itself in a dynamic state of balance. These self-organizing mechanisms enable it to pass from one state (or "attractor") to another in different ranges of parameters, as well as evolve in time by undergoing major discontinuities (or "bifurcations"). Complexity or self-organization theory was first elaborated by chemist llya Prigogine and further developed by biologists Humberto Maturana, Francisco Varela, and Stuart Kauffman as well as sociologists such as Niklas Luhmann. I argue that the shift to a "dynamical systems" view was a step taken by the founder of modern baroque studies, Heinrich Wölfflin. Wölfflin's formalist and morphogenetic account of the baroque aesthetic can be linked to the dynamical systems model, which prioritizes wholes and patterns of relationships over the independence of parts, just as his account of Renaissance classicism can be seen to embody the dominant modern analytic paradigm, which anatomizes wholes by breaking them into parts. Reversing the dominant modern relationship between parts and wholes, Wölfflin placed the baroque squarely within the twentiethcentury paradigm shift from the analytical to a holistic or complexity approach.

Claire Farago. For the past year I have been working on a research topic centered on early seventeenth-century Rome that bears directly on the construction of chronological turning points, specifically on the locus classicus for the transition from the Late Renaissance to the baroque in painting. Why is Caravaggio's work still seen as an interruption in linear developmental schemes of periodization? ${ }^{12}$ In my current research, Catholic Reformation-minded ecclesiastics who were also major art collectors and directly involved with the recently established Roman Accademia di San Luca initially supported Caravaggio. ${ }^{13}$ Cardinal Francesco Maria del Monte was Caravaggio's first major Roman patron as well as protector of the Roman Accademia di San Luca. At his death in 1626, the recently elected Pope Urban VIII appointed his 27-year-old nephew Francesco Barberini as Cardinal-Protector of the Accademia. Cardinal Barberini built his own art collection by acquiring many works from the estate of del Monte. Soon, however, he directed his patronage to the new modern style exemplified in the work of Pietro da Cortona, whose bravura brushwork and dynamic compositions consisting of voluminous, dramatically foreshortened allegorical personifications and historical figures praising the Barberini family soon decorated the ceiling of the family palace. The poetics of the grand manner that also came to be practiced by sculptors like Bernini can be identified with/as epideictic rhetoric, that is, highly embellished praise in visual form. ${ }^{14}$ This new, elevated "modern" style distinguished Barberini's taste in monumental painting from other alternatives, including the very different dramatic effects of Caravaggio and the caravaggisti, and Poussin's restrained historie long associated with Albertian decorum transposed to the visual register from the Ciceronian middle style. ${ }^{15}$ Yet Cardinal Barberini also continued to sponsor publications where optical naturalism focused on documenting objects and specimens "scientifically" was effective and preferable.

I can say unequivocally that the period term "baroque," with its inevitable shadings of style (in the modern sense of that word), is both anachronistic and misleading when it is applied to the historical circumstances in which art historians of the nineteenth century (but not earlier) located a major periodic threshold. ${ }^{16}$ Furthermore, the concept of periodization is unnecessary to do historical work - nor is it desirable in my view. ${ }^{17}$ My own engagement with period/style terms is historiographical - because so much is invested in our archives, I engage these terms in order to unpack them. 
5. Peter Greenaway, installation view of Leonardo's Last Supper: A Vision by Peter Greenaway, exhibited December 3, 2010-January 6, 2011 at the Park Avenue Armory, New York.

Stefano Jacoviello. Through perseverance, Wölfflin and Eugenio d'Ors ${ }^{18}$ freed the baroque from the fetters of chronology, transforming it into a particularly fruitful space of reflection. This shift has been relevant not only for the history of the arts and aesthetics but for studies on culture in general. Reasoning through anachronisms, and pointing out common forms and devices in objects pertaining to diverse periods and fields of knowledge, helps to intimately understand Seicento works while at the same time showing how and why they concern us. That is the path I usually try take in my research about music, between semiotics and theory of arts.

In musicology studies, which usually fluctuate between a philology radically rooted in the sources - described as finds - and reflection on the socio-historical reception of the works, the baroque is typically treated as something self-evident. Coping with the impossible congruence of authors like Gesualdo, Monteverdi, Frescobaldi, Vivaldi, Bach and Leo without relying upon mere chronological labels (late, early, full...) does not seem so intriguing to the majority of scholars.

Nonetheless, as Deleuze says, "irregular pearls exist, but the baroque has no reason to exist without a concept that forms this very reason." ${ }^{19}$ Therefore, while fully respecting the musical sources, in my opinion, the analysis of specific formal configurations can lead to rediscovering in the folds of Monteverdi's compositions those devices aimed at endowing sound with a vibrant sensuality. Through the application of those devices, which establish the traits of a new musical discourse, the listener is transformed into a world where passions clash and music becomes an experimental field for observing the physics of the soul, similarly to the way in which Galileo's instruments were utilized to explore the external nature of the world. ${ }^{20} \mathrm{~A}$ deep structural understanding of how Monteverdi's works relate to the birth of modernity in music can additionally highlight the features of the epistemic turning point we call the baroque.

Furthermore, an approach of this kind may help to understand how Domenico Scarlatti provided the listener with a sentimental role, one that not only resurfaces in the work of François Couperin or Jean-Philippe Rameau but that also emerges in the structure of the beholder in the paintings of Alessandro Magnasco, Fra Galgario, Canaletto, Bernardo Bellotto, Francesco Guardi and up to William Mallord Turner. ${ }^{21}$

All in all I think that "baroque," rather than providing concepts for classifying objects created between the sixteenth and eighteenth centuries, can be useful in that it teaches us to examine the cultural phenomena of every period through a certain lens. The comparative use of its formal models can reveal how Peter Greenaway's (fig. 5) ${ }^{22}$ or Paul Klee's work on images or György Ligeti's on sounds

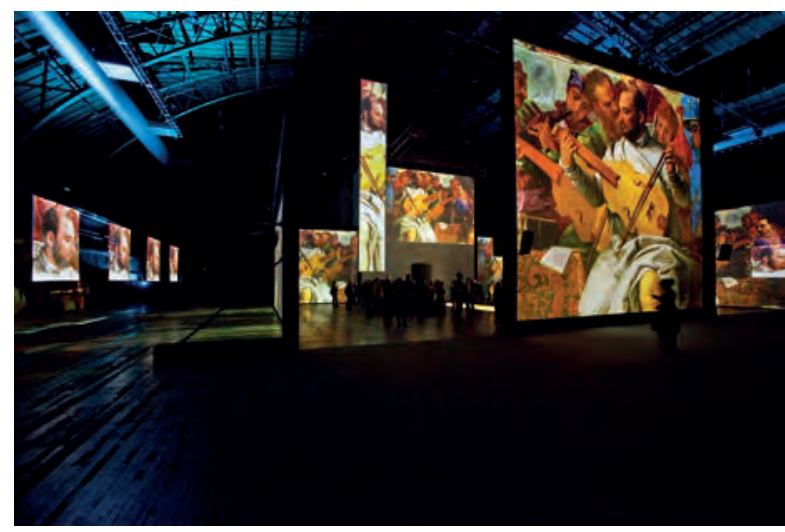
operate. ${ }^{23}$ And it is not so much because their works are nurtured by ghosts of the past or by musical remnants, but because they revive and pursue an inquiry of issues raised by Seicento culture: that is, art as a self-reflexive instrument for describing - on an immanent - level forms of sensibility that speak about the way we feel alive.

Jens Baumgarten and Gabriela Siracusano. We would still consider the term "baroque" to be important but mainly as part of a discursive analysis. It can be seen from either a historiographical or a theoretical or conceptual perspective. This leads to the question of different culturally defined "baroques" and different 
- or even conflicting or contradictory - inscriptions in local discourses. This includes a distinct meaning of the term itself and its cultural implications and categories. In studies on the Spanish viceroyalties, the term "baroque" has embraced diverse and sometimes opposing styles, giving rise recently to conflicting uses. Because of the different existing discourses of the "baroque," there is no one chronological definition but several, which have to be considered in their respective contexts.

The label is also important because it is, in our opinion, one of the founding terms of art history as a discipline. The style paradigm, and its importance in establishing art history as a "science" (Wissenschaft), plays a crucial role, as does the continuing debate about the term and its different discourses. When teaching we characterize the baroque as a dazzling notion that everyone seems to agree upon spontaneously but one which, when one is asked to define it, leads to rich discussions and debates.

Jens Baumgarten. One of my research fields is to analyze the different traditions of the baroque in Europe and Latin America - its differentiations and contradictions.

Gabriela Siracusano. As for studies regarding the material dimension of Spanish American artistic production, it is worth saying that, although the art of Spanish, native, mestizo and creole artists may have displayed materials and techniques similar to those used on the Old Continent, they applied diverse and original strategies to create images seemingly quite different from those that, over time, came to be understood as baroque in the historiography.

Jens Baumgarten and Gabriela Siracusano. As important contributions to the field of baroque we would emphasize the "classics" from Wölfflin, Erwin Panofsky, Benjamin, $\mathrm{d}^{\prime} \mathrm{Ors}$, and Germain Bazin, including the neobaroque works of Omar Calabrese. ${ }^{24}$ It depends, however, on whether the baroque is related to early modern arts, which would include a rather large list, or rather to its reception in contemporary arts and culture as analyzed by Angela Ndalianis ${ }^{25}$ or its reception in the political-cultural context of Brazil as examined by Janice Theodoro and Hanna Levy. ${ }^{26}$

Although we would avoid the term "baroque" (as well as Counter-Reformation) in the study of Catholic theory and the politics of visualization, the discourse on the baroque in Latin American and especially Brazilian contexts attracts interest in shifting and flickering "baroques."

As a seemingly universal stylistic phenomenon that connects the early modern, modern, and contemporary periods, the baroque shall be analyzed as a case and model of the globalization of art and art history. While focusing on Brazil, whose modern cultural identity is founded on the idea of the baroque, the cultural context of the baroque discourse will be extended to the spheres of influence of the early modern Portuguese and Spanish empires. The exploration of local adaptations of architectural style and national myths of modernity, for example, can also be helpful. The transcultural approach to the baroque covers the cross-cultural impact of its style, the intercultural and local differentiation of its forms and meanings, its function as a means of cultural hybridization and amalgamation, and its uses as a means of national identity building. The transhistorical approach points to the alleged historical transcendence and universality of the baroque style, as established by late nineteenth century art history, and aims at analyzing the ensuing ideological and aesthetic constructions of history in Latin America.

The global baroque calls for an interdisciplinary method, including different fields of the humanities and social sciences such as economics and anthropology. 


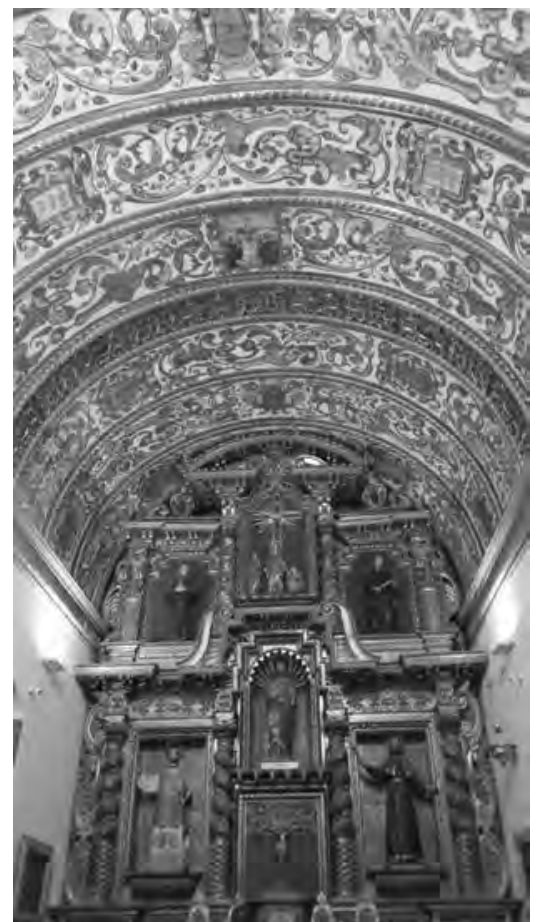

6. Capilla doméstica, Iglesia de la Compañía de Jesús, Córdoba, Argentina.

For example, new approaches like Eduardo Viveiros de Castro's notion of perspectival anthropology and controlled equivocation, or the postcomparative notion of "false friends," 27 can help in analyzing the complexity of the global baroque and in understanding how different visual systems and processes of conflict and negotiation were established in contexts of cultural alterity. This approach can facilitate the reevaluation not only of the relations between Christian colonizers and the indigenous communities, but also between the contemporary scholar and her objects of research, and offers alternative concepts to the dichotomy of center and periphery.

In order to deal with the complexity of a global baroque and avoid the perpetuation of national art-historical traditions and mythologies, it is necessary to compare Latin American baroque, for example, to Asian contexts, and to address the appropriation of the baroque in twentieth- and twentyfirst-century art-historical and political discourses. The formation of an artistic system in the Americas and Asia, ensuing from dialogues and clashes between European models and local prescriptions, will be a major point of discussion. The circulation of art objects, not only between European nations and their colonies, but also among the different colonial settings and between European countries themselves, will be taken into account. For instance, this concerns the formation of an Italian taste in eighteenth-century Portugal, the study of Central European varieties of baroque art, and the cultural differences between German or Italian Jesuit workshops in countries such as Paraguay, Argentina, Chile, and Bolivia (fig. 6), not to mention creative appropriation of baroque aesthetics by the native Guaraní on their own terms (fig. 7).

Helen Hills. In recent years, a wide range of scholarship has re-engaged with the question of baroque and its histories, especially through the work of Walter Benjamin and Gilles Deleuze. How useful is this approach? What are its premises, its promises, and its strengths? What are its weaknesses and its limits?

7. Anonymous, Holy Trinity, eighteenth century, Guaraní Jesuit Mission of the Holy Trinity, Paraguay.

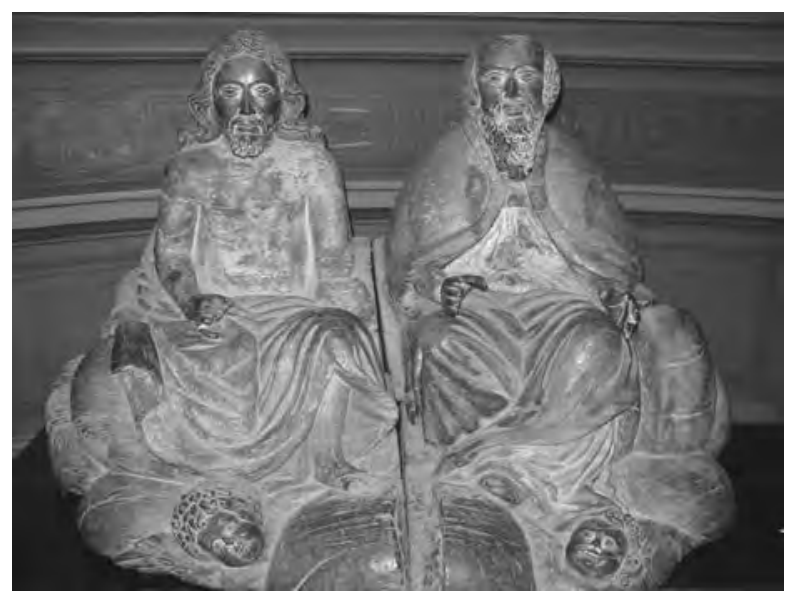

Claire Farago. The writings of Benjamin, Deleuze, and Félix Guattari have been tremendously useful to my own work for a long time. Benjamin's conception of responsible cultural history, epitomized in his statement that every history of civilization is also a history of barbarism, was a formative text for me at the time I was first articulating an ethical imperative for foregrounding crosscultural studies. My theoretical interests in crosscultural research were initially fostered by reading Latin Americanist art historians working on the so-called "Early Contact" period such as Cecelia Klein at the University of California Los Angeles, the first major art history department in the United States to embrace a predominantly non-Western curriculum. I read Klein alongside scholars from other disciplines such as Rolena Adorno, Inga Clendinnen, John Elliott, James Lockhart, Sabine MacCormack, Anthony Pagden, Eric Wolfe, and the French anthropologist Serge Gruzinski, another important writer for me because his work dealt with partial recovery of the 
culturally dispossessed at a time when the very different interpretative standards of George Kubler still dominated the art-historical discourse. In the early 1990s I also read critiques of Eurocentrism written by postcolonial literary critics such as Gayatri Chakravorty Spivak and Homi Bhabha, and political theorists such as Samir Amin, Maxime Rodinson, and Edward Said's Orientalism (1978), which was the galvanizing text for my 1995 Reframing the Renaissance project. ${ }^{28}$ African Americanist literary historian Henry Louis Gates, Jr., was another formative voice for me in those years.

Benjamin helped me give voice to what is urgently at stake in the re-writing of art history. Deleuze's critique of transcendentalism has been widely influential, far beyond the association of the fold with the word baroque. Specifically, the Deleuzian concept of a rhizomatic structure developed by Bruno Latour in his Actor-Network Theory (ANT) account of agency is widely being used and also worth discussing here in the context of debates over the term "baroque." ${ }^{29}$ According to this Deleuzian model, agency is relational in the way stuff is connected. This means that materials (things, but not just things, anything material ranging from water to tar to electricity) are acknowledged to have agency of their own (Deleuze and Guattari call them nonhuman "actants"). ${ }^{30}$ Deleuze and ANT encourage attention to the semiotic power of materials as they are fashioned into works of art. It is this account of the work of art as an "event" occupying an interstitial state of "in-betweenness," and not the word "baroque" per se, that is an important tool in today's toolbox.

Stefano Jacoviello. To be honest I am not yet familiar with studies in my research field that refer to Benjamin in this sense. Reflections made by aestheticians on the Ursprung des deutschen Trauerspiels (the mourning play or tragic drama) ${ }^{31}$ usually produce an examination of Benjamin's own thinking on the baroque or, generally, about music, instead of dealing with its eventual application to other "objects", ${ }^{32}$ as is perhaps the case with Passages or Angelus Novus.

Otherwise, if we understand the baroque as an epistemic structure, or a stylistic configuration crossing periods and forms of culture, there are many concepts propounded by Deleuze (not only in his book on Leibniz) that show an obvious efficacy if projected from the past time when they were created onto the contemporary, the scene of their applicability. Obviously, any anachronism should be subjected to proof of the texts and squared with their possible resistances to avoid the risks of a baroque "wandering theoretics."

The fold, the consummate baroque device, ${ }^{33}$ helps for example to understand the efficient mechanisms of the "tactile" digital images submerging us. The notion of the fold offers a philosophical set of tools for understanding the present-day slipping of the aesthetic paradigm from illusion to simulation ${ }^{34}-\mathrm{a}$ shift that had already occurred with the so-called rococo when the pictorial over-ripeness of still lifes acquired the substance of inlays and gilded stuccoes to be immediately "experienced" in the space "beyond" the representation.

The replacement of the "matter-form" pair with "material-power," as pointed out by Deleuze, ${ }^{35}$ enables us to describe the substantial effect of the sound that, in the instrumental and vocal music of various early eighteenth-century authors, reveals its texture and is discharged, expelled from the order of musical time, to present itself to the listener as "object-matter" that is to be listened to and experienced. In the field of images the unfolding form triggers from within an impulse that is manifested on the outer surface as a tangible force, overflowing the edge of the figures and acting on the aesthetic experience's subject by means of a conformation. ${ }^{36}$ 


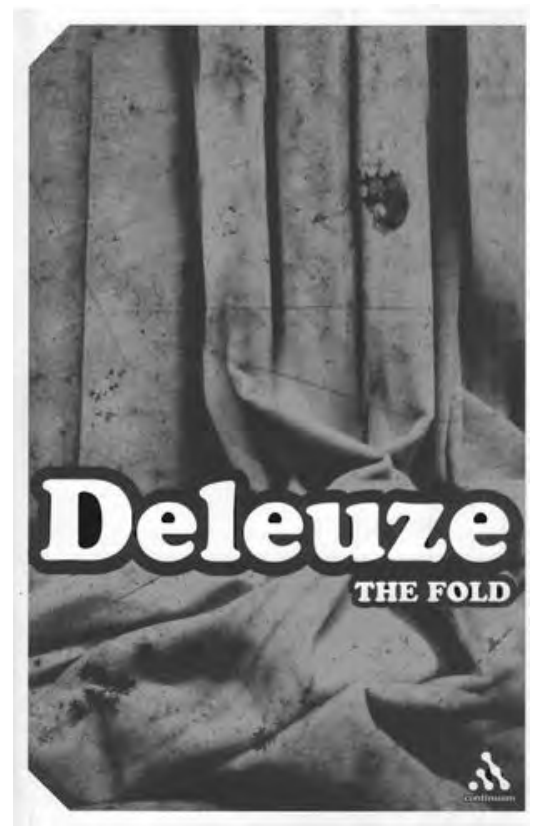

8. Gilles Deleuze, The Fold: Leibniz and the Baroque, Minneapolis, 1993 [Fr. ed.: Le Pli : Leibniz et le Baroque, Paris, 1988].
In Mille Plateaux, Pierre Boulez's interwoven reflections on the pairing of "smooth" and "striated" led Deleuze and Guattari to suggest an interpretive key for the effect of musical sounds that are drawn out in a non-pulsed tempo: the matter explicitly renders itself as material, and lets emerge on its surface the forces that shape and arrange it as in a continuous modulation. According to this, certain "ambient" music can reasonably be defined as "baroque."

Monika Kaup. Walter Benjamin's theory of baroque allegory, a study on German baroque plays (Trauerspiele), and Gilles Deleuze's theory of the fold, a reading of Gottfried Wilhelm Leibniz (fig. 8), are two important neobaroque theories that nonetheless lead in opposite directions: Benjamin's theory of baroque allegory and melancholy is part of his theory of Western modernity as catastrophe. Deleuze's theory of the baroque fold, in contrast, investigates the baroque as a creative principle. Together, Benjamin's and Deleuze's theories, each an equally important part of the baroqueneobaroque network, illustrate the complexity of the baroque. Benjamin views baroque allegory as a critical, de-mystifying mode of insight that shatters the false harmonies of the dominant modern ideology of progress. This is connected to the baroque cult of the ruin: allegories are word-ruins that present objects in states of decay and destruction: "Allegories are, in the realm of thoughts, what ruins are in the realm of things." ${ }^{37}$ The way that baroque artwork presents things - in a late, exhausted stage, as broken, discarded detritus is reproduced at the level of the baroque artwork's poetics of fragmentation and artificial construction. The theory of baroque allegory and melancholy in The Origin of German Tragic Drama seeded Benjamin's theory of modern history as catastrophe in his 1940 essay "Theses on the Philosophy of History." ${ }^{38}$ The angel of history sees that modern history is not continuity and progress, but a pile of debris that grows skyward. The angel's revelation, conditional on a backward glance (he is writing history against the grain of chronology, by looking backward), is also a neobaroque instance of the baroque play of illusion and disillusionment: the baroque is a theatrical, nonobjectivist mode that explores slippages between appearance and truth, deception and insight. Conversely, in The Fold, Deleuze explores the sunny face of the baroque - as it were - the other side of the coin of Benjamin's melancholic neobaroque. Deleuze's baroque fold is not an instrument of critique as is Benjamin's baroque allegory, but a mode for the speculative creation of worlds: the "baroque solution," writes Deleuze, is to "multiply principles." ${ }^{39}$ One might say that Benjamin's baroque is epistemological, whereas Deleuze's baroque is ontological. The baroque fold that "unfurls all the way to infinity" 40 is a dynamic principle, expressing a becoming not premised on being. By developing Leibniz's pluralism, which sought an alternative to the dominant modern principle of Cartesian dualism, the Deleuzian fold demonstrates that the baroque is an alternative, nondissociative modernity, a modernity that hybridizes and weaves networks instead of purifying and dividing.

Helen Hills. Scholars across a wide range of disciplines have tangled with the term "neobaroque." Which directions in the existing scholarship have you found or do you find most productive and in what ways? 
Gabriela Siracusano and Jens Baumgarten. How does one write visually about the Brazilian baroque and the translational processes of theoretical concepts and therefore, implicitly, about the relations to the neobaroque? And how does one create a baroque canon? In my research I refer in particular to recent studies by Angela Ndalianis and Walter Moser. In her works on the neobaroque, Ndalianis, a film, art, and cultural historian, compares the media and entertainment culture, especially since the 1930s, with the so-called historical baroque of the seventeenth century. Paraphrasing Henri Focillon, she defines a trans-historical and -cultural baroque, namely a form that has dynamically and constantly shown its presence across the centuries, with varying degrees of intensity. The moments of greatest intensity are those that interest her most. In her research she works predominantly with two concepts that are related to the trans-cultural concept of the neobaroque: the teatrum mundi and the Wunderkammer. ${ }^{41}$ Her epistemological interest in the neobaroque paradigm leads her to examine the historical relevance and effectivity of a so-called baroque concept, developed post factum in the second half of the nineteenth century in reaction to a certain form of "high culture," and especially its reappearance in contemporary entertainment culture. This baroque created a fascination (Faszinosum) on the level of the cultural discourse as well that of cultural practice. Moser, in his cultural theoretic studies about the neobaroque, advances the hypothesis that the baroque was conceptualized as a rhetorical and aesthetic device (puissance) that was wielded differently in different media, as well as in distinct technical, politi$\mathrm{cal}$, and socio-economic contexts. These approaches serve to analyze the potential of modern and contemporary entertainment culture to fully realize the baroque aesthetic of efficacy. Considering the political aspects of this approach of a neobaroque aesthetic, it can be understood as a "democratized baroque" that levels hierarchical differences between so-called high and popular cultures and finally radicalizes trans-cultural mobility into a globalized paradigm. Thus the neobaroque, through trans-medialization, recycles the baroque, its efficacy, and its historical topoi for contemporary mass culture. Teatrum mundi and Wunderkammer were always related to, and therefore contribute to, a theoretical debate on reality, virtuality, simulacrum, and spectacle.

In her analysis of entertainment culture, including the decoration of casinos in Las Vegas, with their architecture of effects, Ndalianis shows their parallels to sixteenth- and seventeenth-century cabinets of curiosity. The interior spaces in particular evoke and join different fragments from the whole world, thus creating an impression of sensorial immersion. One need only to think of the architecture of the Venetian Casino or Caesar's Palace, with its Ancient Roman and Renaissance architecture and decoration: views of architecture, media displays, music, smells and tastes of different "Food Squares," tangency of different textures, sculptures, and products of consumption. Like in the early modern Wunderkammer, where the macrocosm is represented in the microcosm, the complete entertainment world is presented and represented in the microcosm of the Las Vegas casino. ${ }^{42}$ The sensorial experience is therefore decisive for the interpretation of neobaroque spaces with their technological and - in the literal sense - spectacular wonders; multiple perspectives, axes of gaze, and sensorial experiences multiply the rare, special experience referred to in René Descartes' definition of admiration in his Discours de la Méthode. The spectator shifts to an intellectual register when he evaluates his miraculous, almost mystical experience. Each saltation in visual observation leads to a shift in the sensorial perception of the spectator, when the position of spectator/consumer is changed in a continuous process of evoking other transformative miraculous experiences. This process also ensures the virtuosity of the artist-architect as central to the spectator's experience of the performance. ${ }^{43}$ 

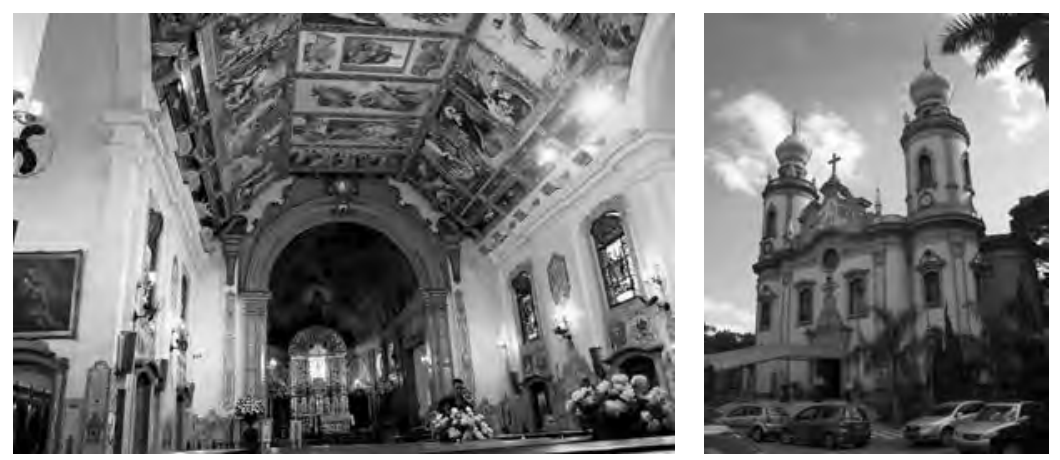

Jens Baumgarten. In my own research I analyze the architecture, decoration, and other visual material of the church Nossa Senhora do Brasil, one of the best known and most impressive churches in São Paulo, which can be classified as neo-baroque (fig. 9). The church combines different elements that reflect a political, religious and aesthetic project of Brazilian culture and history. It also shows the configurations

9. Church of Nossa Senhora do Brasil, São Paolo, façade and interior. of the discourse about an historical baroque and a transcultural and -historical neobaroque. The architecture and decoration clearly reflect the idea of the relationship between Brazilian and European art history within a concept of one common baroque. The church thereby aims, through visual discourse, to establish a political, religious, and aesthetic position for the city, with its multiethnic emigration groups, as well as in relation to the Brazilian "national project" of positioning itself as an inclusive "racial democracy" (democracia racial). Additionally, I discuss the historiography on the historical baroque as a starting point to analyze specific notions of neo-baroque discourse in the Brazilian visual arts. This second topic seeks, through a case study of the art historian Hanna Levy, to demonstrate the importance of developing a transcultural neo-baroque. My intention is to focus on the ways in which baroque art is discussed in Brazil and the place that it occupies at the crossroads between Brazilian and European art historiography.

Stefano Jacoviello. In music the term neobaroque usually recalls the present revival of stylistic elements of the seventeenth- and eighteenth-century discourse on music, and most notably the position of the virtuoso, including recuperation of some clothing accessories (hats, frills...). It also can refer to a way of executing eighteenth-century compositions, highlighting connections with present modes of producing, experiencing, and consuming music, with an eye on the market.

This has nothing to do with the neobaroque conceived by Deleuze as the evolution of the baroque harmony towards the coexistence of incompossibilities: a pleasingly unresolved aesthetic of paradox arisen in the late nineteenth century with the elevation of chromaticism as a principle of overall regulation of the musical form and whose highest expression is Boulez's "polyphony of polyphonies." 44

I maintain that Omar Calabrese with his L'età neobarocca and other later texts, ${ }^{45}$ in the wake of Wölfflin, d'Ors, Focillon, Severo Sarduy, and Kubler, and blending semiotic tools with the art theory of Louis Marin, Hubert Damisch and Daniel Arasse, outlined an effective conception to analyze cultural phenomena that, though appearing very different, can be attributed to a common episteme. For Calabrese the neobaroque is a category of a social aesthetics - crossing every field of knowledge (art, science, customs) - that considers aesthetic value relevant not only to the works and their producers' intentions, but also to the audience and the way its members consume those works, through an action that expresses a taste. Nevertheless, as much as the neobaroque could be understood as a re-emergence of the sixteenth-century "forma del vivere" (Baldassare Castiglione, 1528), it does not arise either deterministically or logically as the evolution of the baroque. Through an anachronistic approach, Calabrese's method examines the adequacy and effectiveness of the historical baroque's formal categories 
through the analysis of today's cultural phenomena. This comparative investigation, arced backwards from the present to the past, aims to identify the theoretical similarities as well as the practical differences that depend on the specific habits in consuming cultural objects present in diverse communities and periods. Current morphological trends in art production toward restraint or excess, fragmentation, and instability find an echo in the scientific approach, which is tending toward complexity, dispersion, indetermination, and approximation. Thus we discover a direct nexus between these formal categories and their expression in social practices. So it is easy to understand why neobaroque was often superimposed on postmodernism, and at the same time it is clear why baroque revival, which is satisfied with a superficial likeness to the baroque without embedding its aesthetic principles, has nothing to do with the neobaroque.

This inquiry on style in contemporary culture reveals similar forms of sensibility in objects belonging to different periods, which are anachronistically united in the aesthetic and epistemic attitudes of a subject with baroque tastes, thereby disclosing profound cultural dynamics that would otherwise be concealed by the outward characteristics of isolated artistic and social phenomena.

Helen Hills. Is there a sense in which the "baroque" is implicated in the Spanish/ Portuguese/Iberian colonial project? If so, in what ways? Please sketch the implications of this in terms of rethinking colonialism. If you do not accept this, please explain the grounds on which you think this approach unhelpful.

Claire Farago. First one has to ask when the term baroque matters; then where, what the alternatives are, and how such terms matter at all. Regarding the "when" question: if we take the term "baroque" to apply simply to the seventeenth century throughout the world, many things will not seem to fit - they will "appear out of sequence." 46 Regarding the "where" question: among the first art historians to offer synthetic histories of Latin American art was Pál Kelemen, who attempted in Baroque and Rococo Art in Latin America (1951) to establish colonial art within the same stylistic continuum that governed European art. ${ }^{47}$ In this respect, his intervention was no different from what Dmitri Sarabianov, for example, attempted to do in writing the history of westernized Russian art for a Euro-American audience. ${ }^{48}$

Regarding the question of alternatives. Monika Kaup argues that the Deleuzoguattarian theory of emergence was anticipated in the structure of a New World baroque. ${ }^{49}$ The history of the history of Latin American art began to change in the 1970s. Although it drew examples almost exclusively from Spain, José Antonio Maravall's study Culture of the Baroque became a touchstone across the humanities because it stepped away from formalist categories and put questions of media, power, and technology at the center of discussion of the baroque as a "historical structure." 50 Critical response to Maravall's top-down approach encouraged productive attention to counter-hegemonic discourses on the same terms, for instance, on the question of how the colonial imposition of authority opens onto complex maneuverings and transformations within colonial societies. Walter Mignolo writes in these terms about the Barroco de Indias as the angered expression in art and ideas "built upon colonial expression and the colonial wound." ${ }^{51}$ Mignolo and a newer generation of writers who employ de-colonial rather than neo-colonial strategies insist that the aesthetics of the modern be expanded to include the entire world, and the scene of cultural production be explored historically - meaning that studies of coloniality include the 
viewpoint and contributions of the culturally dispossessed and the politically and economically oppressed, even and especially when individuals remain anonymous in the historical record. ${ }^{52}$

So on to the final question: how does the term baroque matter now? Helen Hills recommends retaining the baroque understood as a mode of translation that resists the singular translation of one sign to another and offers instead the possibility of engaging with the material without treating materiality too hastily as the instantiation of an idea..$^{53}$ I agree that Deleuze's baroque refers to a trait, a specific way of thinking that endlessly produces folds. I have written elsewhere about the complexity of constructing subaltern readings of "baroque" art. With regard to the discourse on idolatry, which was a major concern in cross-cultural interactions during the opening century of global contact, Protestant Reformation theologians renounced lavish religious displays and material aids as idolatrous while their ecclesiastic counterparts in New Spain and Brazil levied charges of idolatry against their newly colonized subjects on the same grounds. ${ }^{54}$ European associations of the baroque with the exotic, the abstruse, the strange, put ritual practices and material culture rooted in the indigenous Americas in the conflicted position of being regarded as grotesque signs of moral corruption at the same time that the same so-called "idols" were also regarded as signs of the subtle creative powers of the human imagination, especially once the objects were domesticated and re-functioned in European Wunderkammern.

Benjamin's critique of historical time as chronology rejects notions of periodization by emphasizing how the past is imbricated within the present. ${ }^{55}$ To give an example: by the end of the nineteenth century, the controversial and contradictory past of the "baroque" was largely occluded from view. The complex foldings and re-foldings that resulted in mutually-inflected cases of cultural interaction are still rendered invisible by conventional sub-disciplinary categories organized by geographical location and time period. For this reason, an emphasis on the trans-oceanic baroque and the technologies employed to ensure the operation of society and the transmission of cultural knowledge (and of cultural amnesia) are needed. Porous, flexible, folding past into future and re-folding what is in-between in order to undercut the anachronistic cultural and aesthetic boundaries that interfere with our ability to see the complexity of interactions. To practice a Benjaminian/Deleuzian cultural history, we must utilize a "double vision" - to borrow a term from Joan Kelly ${ }^{56}$ - by looking both "inside" and "outside" the frameworks traditionally associated with the baroque.

Stefano Jacoviello. If we want to analyze the connection between the Spanish/Portuguese colonial program from the sixteenth to eighteenth centuries and the baroque, we obviously have to view the latter as a historically determined cultural and artistic experience. Certainly the "normative" or "normalizing" commitment of Catholic Europe (of the time) with regard to the world was prodigal in the operation of conquest and unfolded in the missionary adventures of the Franciscans and Jesuits. Things are more complicated however - more baroque, so to speak.

The Jesuits who set out on the route to the East brought to the coasts of India and East Asia a great number of musical instruments and utilized them for predication so effectively as to convince the locals to learn to use them for the same purpose: such was the fate of the harmonium, which passed from the hands of the Portuguese to those of the Chishti Sufis with the resulting restructuring of the Indian modal system in line with the intonations offered by this tempered instrument. 
In China and Japan Francesco Saverio and Matteo Ricci found musical grammars whose principles were analogous, by translating them, to those Greek modes that were being discussed at the time in Italian intellectual cenacles. Ricci imported Persian instruments to China that had been reconstructed in Flanders; he wrote songs to be translated in Chinese and encouraged writing methods to teach the harpsichord. As a result, after their initial distaste for the polyphonies widely in use at the court of Charles V, Chinese nobles began to appreciate instrumental sonatas and request that they be performed during public ceremonies. In line with Ricci's approach, ${ }^{57}$ we observe in China a reciprocal translation of musical forms, which nonetheless remained distinct and were almost never mutually understood. ${ }^{58}$

The polyphony that had disgusted the Chinese nobles was instead successfully imposed by the Franciscans in New Spain and efficiently exported by the Jesuits in South America. But here things took a more interesting turn: although Spanish and Italian music was used as an instrument of conversion and social control, it became at the same time the most efficient artistic form for expressing the taste of the new colonial elites. As such it was easily "tainted" with the musical practices of the Indios and African slaves, producing a corpus of popular music in which features of Jewish-Arabic culture, which the ruling Spaniards and Portuguese had sought to eradicate in their native land, re-surfaced. Composers coming from Europe showed a particular receptivity to the musics of the subjected populations and produced folk hybrids of every kind that were added to the canonical liturgical celebrations or formed new ones ad hoc for the "negros"; at the same time a new musical culture grew, whose roots can no longer be retraced. Yet instead of calling for recognition of an indigenous cultural identity, this musical culture looked instead to the Iberian peninsula, claiming to embody the first true "Spanish" culture, one that never could have existed in that no longer native land. The Caribbean became a baroque place where everything was constantly rewritten and corrected; where anyone could sing the villancicos, interweaving nahuatl and huatxechi poetic verses with Spanish dialects; and where the shapes of guitars multiplied to such an extent that guitar ensembles could compete with traditional string instruments to accompany double choirs in church and a l'italiana arias in the theater.

Rather than an instance of the colonial process, therefore, the baroque was one of its effects that assumed the forms of creolization processes, consisting in the production of multiple identities in continuous reciprocal translation, placed in a highly unstable multidimensional system of social relations, ready for strategic use. ${ }^{59}$ What happened to music in the New World is very similar to what happened to sculpture and architecture in southern Italy, particularly in Salento, and later in some areas of southern Sicily: the baroque aesthetic encountered craftsmen who translated the overall formal principles, creating an utterly original artistic experience scarcely comparable to the more formal expressions of the baroque, save for a certain "family resemblance." 60

Moreover, in order to represent the imagery of a baroque Mexico, many Spaghetti Western movies found their ideal landscape in the countryside of southern Italy, dotted with small churches perhaps resembling those of the Franciscans and Jesuits built on the other side of the ocean. This reversed creole neobaroque creative practice gave recent American western movies "baroque-like" settings and sounds - which had not existed in previous "indigenous" US productions -, together with a new visual identity and a perspective on a picturesque past that unexpectedly includes Latinos (and sometimes Afro-Americans as well). In all of its forms, baroque seems still to be ironically connected with the cultural dynamics of colonial processes. 
Monika Kaup. The baroque originated as the repressive tool of European absolutism and the Counter-Reformation; its arrival in the Americas was due to European colonialism. In Alejo Carpentier's words, the baroque first reached the Americas on the ships of the conquistadors. ${ }^{61}$ The baroque's beginnings as an authoritarian style raise questions about the baroque that grew up in the Americas: was it nothing but a reactionary force, a derivative of the colonial European baroque? It was not until the post-World War II period that a generation of Latin American and Caribbean writers and cultural critics (Cubans Alejo Carpentier and José Lezama Lima, Brazilian Haroldo de Campos, Martiniquan Édouard Glissant, and others) popularized the idea, first proposed by Argentine art historian Ángel Guido in the 1920s and 1930s, that the baroque had worked poorly as a colonizing instrument in the New World. There, it had gradually been adapted and transformed at the hands of the indigenous, mestizo and mulatto artisans and artists who crafted the monuments of the baroque overseas, thereby creating the rebellious New World baroque, a transculturated and mongrelized hybrid that inserted pre-Columbian and local elements into the iconography of the Catholic baroque. In Lezama Lima's memorable phrase, the New World baroque was not the instrument of the CounterReformation, but of counterconquest (contraconquista). ${ }^{62}$ As critics such as Lois Parkinson Zamora, César Salgado and Carlos Fuentes have noted, this is one of colonial history's few satisfying ironies: somehow, the colonizer was himself colonized.

This said, two important observations are needed: first, the emergence of the transculturated New World baroque would not have been possible without some level of official tolerance. The process of transculturation underpinning the New World baroque is actually a dialectical process, whereby the decolonial transculturation "from below," which sought to Indianize Christianity, co-existed alongside official modes of transculturation "from above," which in turn sought to Christianize indigenous culture. The most famous instance of the latter was the Jesuit missionary policy of syncretism. My second point is theoretical: the Latin American counterconquest baroque illustrates the substantial creative possibilities of baroque aesthetics. For the baroque is a second-hand, non-original, or dependent mode of creation: creation by way of recycling and re-creation, rather than by creating from scratch. The baroque is a way of saying something new by remaking the old. The New World baroque's rebellious remaking of the European colonial baroque is an instance of appropriation (Stuart Hall) and of the becoming-minor of a majoritarian cultural formation (Deleuze and Guattari). It is dependent rather than autochthonous by virtue of being built on a European base. Its decolonial function is in deforming and overwriting the alien, colonial text.

Jens Baumgarten and Gabriela Siracusano. The baroque seems to be interwoven not only geographically/culturally but also from a generational and disciplinary point of view. In the case of Brazil, visual art histories point to the connection of the baroque and the neo-baroque to other terms that are similarly amorphous, like "modernity" or "national art." As an example, it is worth mentioning the debate between Antônio Candido, João Adolfo Hansen and Haroldo de Campos regarding the term and notion of baroque in the formation and definition of a Brazilian national literature. ${ }^{63}$ The debate concerned parallel epistemologies within a national discourse and, implicitly, their transfer to the academic setting.

The discussion about the baroque has evolved into a political and historical conversation about the formation and transformation of a specifically lberian modernity. It is also revelatory that this exchange of ideas has largely taken place 
without the participation of art historians, who should be intrinsically interested in questions of representation. As for the Spanish viceroyalties in South America, the category of "baroque" is sometimes related to the necessity of defining borders within national identities, such as Barroco Peruano, Barroco Andino or Barroco Mestizo, categorizations that in many cases are confusing or even contradictory. It can also refer to a wide range of artistic and architectonic productions created mostly within the eighteenth century (fig. 10). The discourse constructed around the baroque and its relations to the neobaroque contains irresolvable paradoxes opposing historicist and theoretical approaches, yet it nonetheless attempts to overcome these tensions.

There are different phases of neobaroque use and re-use: a first one along with modernist ideas, a second one as a religious-aesthetic foundation of neobaroque theology, and a third one that Walter Moser has considered the baroque form of using, the neo-baroque aesthetic. The neobaroque in Latin America also inscribes itself in the conservative tone of a hierarchical appropriation of the baroque, including its function in popular culture and a parallel appropriation of its subversive character. These neobaroques present different art histories: aesthetic, religious, and political. They narrate and visually present the art history of the baroque in a neobaroque manner. They re-negotiate the impacts of nationalism and modernism and fold them in the baroque discourse as a relation between Europe and Latin America. Therefore we can speak of a return to and a return of the baroque.

The baroque and the neobaroque present in Latin American art since colonial times can be considered to be (almost) a "second neobaroque foundation" of Western art. Yet, since it is a version of Western art that follows its own internal rules and patterns, it seems complicated to position it in relation to European and Northern American art or to define it as native or as postcolonial art as opposed to European, Western art. The project of national art since the nineteenth century can be understood as a reflection of the European model; it was based on the idea of "colonial art," in which the concept of the "baroque" functioned as a catalyst for revising the model. ${ }^{64}$ Contrary to Europe, where art created roots and traditions, in the Americas this ideal was transformed in the hands of artists who were more ambitious to know how to create than to copy. "Baroque" and neobaroque art in Brazil was an art made without questioning its subjectivity. This specificity of Brazilian art resulted in a lack of intellectual tradition dedicated to art-historical studies. This does not imply the absence of the field of art history in Brazil; it simply means a stronger presence of a baroque and neobaroque visual language - representations that in an Iberian tradition more strongly express the amalgam between subject and object than their separation.

Recent debates within the writing of world art history have broken with references to the Brazilian reflection of Europe, the national paradigm; they seem to prefer an approach that follows a rather ethnically determined paradigm. Levy found a third way that could serve as stimulant or a meta-theoretical impulse for further developments of an art history of the baroque and the neobaroque.

Stefano Jacoviello's contribution was translated from Italian by Susan Wise. 
1. Mieke Bal, "Baroque Matters," in Helen Hills ed., Rethinking the Baroque, Farnham, 2011, p. 183-202.

2. Andrew Benjamin, "Surface Effects: Borromini, Semper, Loos," in The Journal of Architecture, 11/1, 2006, n. 1, p. 1-35. See also Helen Hills, "Rethinking the Baroque," in Hills, 2011, cited n. 1, p. 3-37.

3. Heinrich Wölfflin, Renaissance und Barock: Eine Untersuchung über Wesen und Entstehung des Barockstils in Italien, Munich, 1888; Walter Benjamin, Ursprung des deutschen Trauerspiels (1928), Rolf Tiedemann ed., Frankfurt-am-Main, 1963 [English edition: The Origin of German Tragic Drama, London, 1985].

4. Irlemar Chiampi, "The Baroque at the Twilight of Modernity: Chapter 1 from Barroco y Modernidad," in Lois Parkinson Zamora, Monika Kaup eds., Baroque New Worlds: Representation, Transculturation, Counterconquest, Durham (NC), 2010, p. 508.

5. Alejo Carpentier, "The Baroque and the Marvelous Real" (1975), lecture published in Lois Parkinson Zamora, Wendy B. Faris eds., Magical Realism: Theory, History, Community, Durham (NC), 1995, p. 100.

6. Benjamin, (1928) 1963, cited n. 3; Gilles Deleuze, Le Pli : Leibniz et le Baroque, Paris, 1988, p. 46 [English edition: Fold: Leibniz and the Baroque, Minneapolis, 1993].

7. Grateful thanks to Margaret Littler, Emanuele Lugli, and Mike Savage.

8. Walter Moser, "The Concept of Baroque," in Revista canadiense de estudios hispánicos, 33/1, 2008, p. 11-37, especially p. 11.

9. Monika Kaup, Neobaroque in the Americas: Alternative Modernities in Literature, Visual Art, and Film, Charlottesville, 2012, p. 3.

10. Rasquache is a Chicano vernacular aesthetic of everyday use that combines the recycling of used objects with a baroque taste for ostentation and extravagance. See Tomás Ybarra-Fraustro, "Rasquachismo: A Chicano Sensibility," in Chicano Art: Resistance and Affirmation, 1965-1985, (exh. cat., Los Angeles, Wight Art Gallery, University of California, 1991), Los Angeles, 1990, p. 155-162.

11. "What Comes after Poststructuralism? New Ecological Realisms in Contemporary Theory and Post-apocalyptic Narrative" explores an emergent phase of intellectual change in the wake of structuralism and post-structuralism - a trend towards new realisms. My point of intervention within this broader movement is to orient myself towards a realism of complex wholes, actornetworks and ecologies, rather than realism of isolated parts and things. This ecological approach to things via their connectivity has a strong affinity with the baroque.

12. Itay Sapir's paper "The Repressed Watershed: 1600, the Early Modern, and the Moderne," presented at the College Art Association Annual Conference 2014, began with this question.

13. Claire Farago, "Historical Introduction," in Claire Farago ed., The Fabrication of Leonardo da Vinci's "Trattato della Pittura," forthcoming.

14. Girolamo Tezio, Aedes Barberinae ad Quirinalum, Rome, 1642, is a guide to the Barberini Palace that makes the rhetorical principles of the artistic program and the viewer's response absolutely clear.

15. On Alberti and Cicero, see Michael Baxandall, Giotto and the Orators: Humanist Observers of Painting in Italy and the Discovery of Pictorial Composition, Oxford, 1971. On Poussin's rhetorical strategies, see Todd P. OIson, Poussin and France: Painting, Humanism, and the Politics of Style, New Haven, 2002.

16. See Georges Didi-Huberman, Devant l'image : question posée aux fins d'une histoire de I'art, Paris, 1990 [English edition: Confronting Images: Questioning the Ends of a Certain History of Art, University Park (PA), 2005, with an expanded preface].

17. In agreement with this view, see further scholarship on the issues assembled by Thomas DaCosta Kaufmann, "Malaise dans la périodisation," in Perspective, theme issue "Périodisation et histoire de l'art," 4, 2008, p. 597-601 [English edition: "Periodization and its Discontents," in Journal of Art Historiography, 2, June 2010, p. 1-6].

18. Heinrich Wölfflin, Principi Fondamentali della Storia dell'Arte (Kunstgeschichtliche Grundbegriffe), Munich, 1915; Eugenio d'Ors, Du Baroque, Paris, 1936.

19. “Les perles irrégulières existent, mais le Baroque n'a aucune raison d'exister sans un concept qui forme cette raison même" (Deleuze, 1988, cited n. 6, p. 46).

20. Stefano Jacoviello, Dolce è il tormento: Monteverdi, Poussin e i passi dell'amore, Florence, forthcoming.

21. Stefano Jacoviello, "The Sound of Substance. Domenico Scarlatti and the Capriccio's painting device," in Teresa Malecka, Małgorzata Pawłowska eds., Music: Function and Value, (conference, Kraków, 2010), Kraków, 2013, p. 143-155.

22. Stefano Jacoviello, "Il sacrificio, il devoto, l'immagine e il testimone. L'ultima cena con Peter Greenaway," in Marco Del Monte ed., Far 
comprendere, Far vedere: cinema, fruizione, multimedialità, (conference, Venice, 2010), Treviso, 2010; "In memory of me. Time, space and witness in Peter Greenaway's 'Leonardo's Last Supper,'" in Claudia D'Alonzo, Ken Slock, Philippe Dubois eds., Cinéma, critique des images, Campanotto, 2012.

23. Stefano Jacoviello, "Lumina ad limina lucent," in Stefano Jacoviello et al., Testure, Sienna, 2009.

24. Omar Calabrese, L'età neobarocca, Rome/Bari, 1987 [English edition: Neo-Baroque: A Sign of the Times, Princeton, 1992]; Heinrich Wölfflin, Renaissance und Barock: Eine Untersuchung über Wesen und Entstehung des Barockstils in Italien, Munich, 1888; Erwin Panofsky, Three Essays on Style, Irving Lavin ed., Cambridge (MA), London, 1995; Germain Bazin, L'Architecture religieuse baroque au Brésil, 2 vols., São Paulo/Paris, 1958; Benjamin, (1928) 1963, cited n. 3.

25. Angela Ndalianis, Neo-Baroque Aesthetics and Contemporary Entertainment, Cambridge (MA), 2004.

26. Janice Theodoro, América Barroca: tema e variações, Rio de Janeiro, 1992; Hanna Levy, "Valor artístico e valor histórico: importante problema da História da Arte," in Revista do Patrimônio Histórico e Artístico Nacional, 4, 1940, p. 181-192; Hannah Levy (with an " $\mathrm{h}$ " from 1941), "A propósito de três teorias sobre o barroco," in Revista do Patrimônio Histórico e Artístico Nacional, 5, 1941, p. 250-284; “A pintura colonial no Rio de Janeiro," in Revista do Patrimônio Histórico e Artístico Nacional, 6, 1942, p. 7-79, and "Modelos Europeus na pintura colonial," p. 7-66; "Retratos coloniais," in Revista do Patrimônio Histórico e Artístico Nacional, 9, 1945, p. 251-290.

27. Eduardo Viveiros de Castro, $A$ inconstância da alma selvagem, São Paulo, 2002.

28. For full citations to all the authors cited in this paragraph, and many more, see Claire Farago, "Editor's Introduction: Reframing the Renaissance," in Claire Farago ed., Reframing the Renaissance: Visual Culture in Europe and Latin America 14501650, New Haven/London, 1995, p. 1-20. A French edition of this essay, condensed with a new introduction, is forthcoming as "'Race,' Nation, and Art History," in Jean-Yves Andrieux, Fabienne Chevalier, Anja Kervanto Nevanlinna eds., Idée nationale et architecture en Europe, 1830-1919= Architecture and National Identities in Europe 1830-1919, Rennes, 2006.

29. Bruno Latour, Reassembling the Social: An Introduction to Actor-Network Theory, Oxford/New York, 2005.

30. The capacity of things to act as "quasi agents or forces," actants, a term Latour uses to describe distributive agency. See the discussion in Jane Bennett, Vibrant Matter: A Political Ecology of Things, Durham (NC), 2010.

31. Benjamin, (1928) 1963, cited n. 3.
32. On the subject, among the recent essays published in Italian I suggest: Tamara Tagliacozzo, Walter Benjamin e la musica (ebook), Rome, 2013.

33. The device of the fold holds together an exterior - an everted, stratified surface - offered to the subject's perception as material organized autonomously with respect to the development of an interior - that instead shows itself in its totality "like a jewel-case where the absolute dwells" to a single viewpoint that grasps its intension. Thanks to this coalescence between internal and external, the acquisition of the concept of fold in the aesthetic of the digital image clears the field of all the concerns about the referential performance of images "without imprint," and allows one to concentrate on the effects of surface and intermediality that occupy the space between the image and the beholder's eye. For the relation between "internal/external," "intension/extension," "high/low," see Deleuze, 1988, cited n. 6, p. 44.

34. Stefano Jacoviello, "Lo sguardo del testimone. Etica e estetica e politica dell'immagine contemporanea," in Dimitri Chimenti, Massimiliano Coviello, Francesco Zucconi eds., Sguardi incrociati, Rome, 2010.

35. Deleuze, 1988, cited n. 6, p. 124.

36. Giovanni Careri, Envols d'amour: le Bernin, montage des arts et dévotion baroque, Paris, 1990. In this case, analyzing the effectiveness of the folds of the Blessed Ludovica Albertoni's clothing, the author is referring to the concept of "impulse-image" proposed by Deleuze in L'Image-mouvement : cinema 1, Paris, 1983.

37. Benjamin, (1928) 1985, cited n. 3, p. 178.

38. Walter Benjamin, "Theses on the Philosophy of History," in Hannah Arendt ed., Illuminations: Essays and Reflections, New York, 1969, p. 253-267.

39. Deleuze, (1988) 1993, cited n. 6, p. 67.

40. Deleuze, (1988) 1993, cited n. 6, p. 3.

41. Angela Ndalianis, "Neo-Baroque Entertainment Spaces and Experimental Design," in Gesche Joost, Arne Scheuermann eds., Design as Rhetoric, Basel, 2008, p. 1 and 5.

42. Ndalianis, 2008, cited n. 41, p. 5-6.

43. Ndalianis, 2008, cited n. 41, p. 7.

44. Deleuze, (1988) 1993, cited n. 6, p. 124.

45. Calabrese, 1987, cited n. 24. Some of Calabrese's texts are collected in Omar Calabrese, II neobarocco: forma e dinamiche della cultura contemporanea, Florence, 2013.

46. Thomas DaCosta Kaufmann, "Discomfited by the Baroque: A Personal Journey," in Hills, 2011, cited n. 1, p. 43-98, in particular p. 92.

47. Pál Kelemen, Baroque and Rococo in Latin America, New York, 1951. 
48. Dmitri Sarabianov, Russian Art: From Neoclassicism to the Avant Garde, 1800-1917, New York, 1990.

49. Monika Kaup, "Becoming Baroque: Folding European Forms into the New World Baroque with Alejo Carpentier," in The New Centennial Review, 5/2, fall 2005, p. 107-149. My thanks to my graduate student Raquel Flecha Vega for this reference and for the observation that temporal destabilization combined with a fixed narrative sequence enabled the European concept of the "baroque" to become something new, something criollo.

50. José Antonio Maravall, Culture of the Baroque: Analysis of a Historical Structure, Minneapolis, 1986 [orig. ed.: La cultura del barroco: análisis de una estructura histórica, Esplugues de Llobregat, 1975]; according to Evonne Levy and Kenneth Milles, editors of the interdisciplinary, bi-cultural Lexicon of the Hispanic Baroque: Transatlantic Exchange and Transformation, Austin, 2013, p. 3-4.

51. Walter Mignolo, The Idea of Latin America, Malden, 2005, p. 61-63, citing the Ecuadorian philosopher Bolivar Echeverría on the appearance of Creole identity "from the lower social levels" that was no longer Spanish or Portuguese but properly Spanish American and Luso-American.

52. Here "modern" is defined broadly to include everything since the initiation of global contact, similar to the French usage of the term "contemporain" to designate everything since the French Revolution; according to Sapir, 2014, cited n. 12, p. 7-8.

53. Helen Hills, "The Baroque: The Grit in the Oyster of Art History," in Hills, 2011, cited n. 1, p. 31.

54. Claire Farago, "Reframing the Baroque: On Idolatry and the Threshold of Humanity," in Hills, 2011, cited n. 1, p. 99-122.

55. Benjamin, 1969, cited n. 38.

56. Joan Gadol Kelly, "The Doubled Vision of Feminist Theory: A Postscript to the 'Women and Power Conference,'" in Joan Kelly, Women, History, and Theory, Chicago/London, 1984. And we need more poetry in our language articulating these events; see Anne Waldman, Laura Wright ed., Cross Worlds: Transcultural Poetics, an Anthology, Minneapolis, 2014.

57. Matteo Ricci, Descrizione della Cina, Macerata, 2011.

58. Jospeh Marie Amiot, Mémoires concernant les Chinois, XIII, Paris, 1788.

59. For the concept of creolization as a model for describing the dynamics between cultures in contact, see Tommaso Sbriccoli, Stefano Jacoviello, Shifting Borders: European Perspectives on Creolisation, Newcastle upon Tyne, 2012.

60. Maybe we should also consider that the baroque style that spread over southern Sicily until the early nineteenth century is partially related to the need for reconstructing an ideal recent past, redesigning through architecture the shape of a homeland destroyed by the earthquake of 1693 .

61. "But when the Spanish plateresque arrives in the ships of the conquistadors, what does the craftsman who knows the secrets of the Spanish plateresque find?" (Carpentier, 1995, cited n. 5, p. 100).

62. José Lezama Lima, "Baroque Curiosity," in Zamora, Kaup, 2010, cited n. 4, p. 212-240, in particular p. 213.

63. Antônio Candido, Formação da literatura brasileira, (São Paulo, 1959) Belo Horizonte, 1993; João Adolfo Hansen, $A$ sátira e o engenho: Gregório de Matos e a Bahia do século XVII, São Paulo, 1989; Haroldo de Campos, O sequestro do barroco na formação da literature brasileira: o caso Gregório Matos, Salvador, 1989.

64. This argument is related to the modification of notions of center and periphery, including the distinction between archaic and modern that Ella Shohat and Robert Stam have shown: it is no longer about grafting the archaic onto the modern, but rather using the archaic, paradoxically, to modernize the present in a dissonant temporality. This combines an imagined community from the past with the utopia of an equally imaginary future. See Ella Shohat, Robert Stam, Crítica da imagem eurocêntrica: multiculturalismo e representação, São Paulo, 2008, p. 412. 